\title{
1 An Early Devonian permineralized rhyniopsid from the Battery Point Formation of Gaspé \\ 2 (Canada)
}

3

$4 \quad$ KELLY C. PFEILER and ALEXANDRU M.F. TOMESCU

5

7 kcp276@humboldt.edu; mihai@humboldt.edu

8 ORCID: 0000-0003-1903-8327 (KCP); 0000-0002-2351-5002 (AMFT)

Correspondence: Alexandru M.F. Tomescu

Department of Biological Sciences, Humboldt State University, Arcata, California 95521, USA; mihai@humboldt.edu

\section{Abstract}

The Emsian deposits of the Battery Point Formation (Gaspé, Canada) host the most diverse Early Devonian flora in North America. While most of this diversity has been described from plant compressions, the permineralized component of the flora is incompletely explored. Based on $>15$ axes studied in serial sections, we describe a new anatomically preserved rhyniopsid from the Battery Point Formation, Eddianna gaspiana gen. \& sp. nov.. Eddianna axes are up to $2 \mathrm{~mm}$ in diameter and have a well-developed terete xylem strand with potential centrarch maturation (comprising $80 \%$ of the cross sectional surface area) that features Sennicaulis-type tracheid wall thickenings. A thin layer interpreted as phloem is preserved around the central xylem and an irregular sclerenchymatous cortex forms longitudinal anastomosing ridges on the outside of the axes. The anatomy of Eddianna axes suggests that they represent lower portions, specialized in efficient water transfer, of a larger plant whose distal regions have yet to be discovered. Eddianna, the first permineralized rhyniopsid described from the Battery Point Formation, is one of only four anatomically preserved plants reported from this unit. These fossils reiterate the potential for additional discoveries of anatomically preserved plants in the Battery Point Formation. 
33 Vascular plants underwent their first major phase of evolutionary radiation in the Early Devonian

34 (Banks, 1970; Gensel \& Andrews, 1984; Kenrick \& Crane, 1997; Gensel \& Edwards, 2001;

35 Gensel, 2008; Cascales-Miñana et al., 2010; Hao \& Xue, 2013). Rocks from this time interval

36 preserve some of the oldest vascular plants, which provide information about the evolution of

37 vascular tissues and tracheophyte diversity. While numerous plant species have been documented from Lower Devonian strata, many of these species are incompletely understood. This underscores a need for continued investigations of Early Devonian floras. The majority of Early Devonian plants had simple organization, consisting of undifferentiated, branched photosynthetic axes. These plants have been traditionally assigned to a few main groups, one of which is the Rhyniopsida (Kenrick \& Crane, 1997). The morphological simplicity of rhyniopsids and other Early Devonian plants, in general, provides only a dearth of characters for comparisons, hindering studies of both the systematics and relationships of these plants. In this context, anatomical information on Early Devonian plants can contribute crucial resolution to these questions and discovery of new anatomically preserved fossils continues to be a primary goal of paleobotanical investigations. Demaret (1986), and Huvenia Hass \& Remy (1991), were recognized as a group by Hass and Remy (1991). Phylogenetic analyses by Kenrick \& Crane (1991; 1997) recovered this grouping as a clade, renamed Rhyniopsida (Kenrick \& Crane, 1997), that shared a distinctive type of adventitious branching, sporangia attached to a specialized pad of tissue, and an abscission or isolation layer at the base of the sporangium. Kenrick \& Crane $(1991,1997)$ noted that the three genera share the same type of water-conducting cells seen in Sennicaulis Edwards (1981), termed S-type tracheids, which indicates that the latter is also a member of the Rhyniopsida and the S-type tracheids are another defining feature of this group. Gerrienne et al. (2006) have proposed the phylum (division) Paratracheophyta for the group that includes rhyniopsids (Rhynia, Stockmansella, Huvenia, Sennicaulis) along with Taeniocrada dubia Kräusel \& Weyland and the gametophytes Remyophyton Kerp, Trewin \& Hass and Sciadophyton Steinmann. 
(1981) has been described from pyrite-limonite permineralizations in the Pragian Senni Beds of the Old Red Sandstone, in Wales. Stockmansella, with two species - S. langii Fairon-Demaret, $(1985 ; 1986)$ and S. remyi Schultka \& Hass (1997) - was described from compressions that preserve pyrite tracheid casts in the Pragian Bois d'Ausse Layers of Belgium and the Eifelian Brandenberg Formation of Germany. Huvenia also includes two species - H. kleui Hass \& Remy (1991) and H. elongata Schultka (1991) - reported in the Pragian Wahnbach Schichten and the Emsian Nellenkopfschichten of Germany, and preserved as compressions containing pyrite tracheid casts.

In North America, rhyniopsids have been reported from the Battery Point Formation (Hotton et al., 2001; Gensel, 2005), as part of a very diverse Early Devonian flora. The Battery Point Formation represents sediments deposited in braided fluvial to coastal environments (Cant and Walker, 1976; Griffing, Bridge \& Hotton, 2000). These Emsian rocks (McGregor, 1977) host plants preserved as carbonaceous compressions and anatomically preserved permineralizations. Compressed fossils, known since John William Dawson's early explorations (e.g., Dawson, 1859), have been extensively characterized (e.g., Gensel \& Andrews 1984; Hotton et al., 2001 and, more recently, Gensel \& Berry, 2016), and make this the most diverse Early Devonian flora in North America. In contrast, permineralized specimens of the Battery Point Formation plants have not received as much attention. Only a handful of studies have addressed anatomically preserved fossils of this unit (Banks \& Davis, 1969; Banks, Leclercq \& Hueber, 1975; Banks, 1981; Hartman \& Banks, 1980; Hartman, 1981; Banks \& Colthart 1993; Hoffman \& Tomescu, 2013), which continues to yield new permineralized material. Here, we describe a new rhyniopsid genus from anatomically preserved material in the Battery Point Formation. This study is part of renewed efforts aimed at fully exploring the diversity of the permineralized flora of this important Early Devonian unit.

Eighteen axes of this new fossil are preserved by calcareous cellular permineralization in four cobbles collected by Dr. Francis M. Hueber (Smithsonian Institution-NMNH) in 1965, from the Battery Point Formation, in the vicinity of Douglastown. This unit is exposed between Douglastown and Tar Point, on the southern shore of Gaspé Bay, Québec, Canada, and its age increases from late Emsian at Douglastown to early Emsian at Tar Point (McGregor, 1977). 
94 Therefore, the age of the fossils described here is mid- to late Emsian, ca.402-394 million years

9

0
old (Cohen et al., 2016). Hosting a broad diversity of mid- to late Emsian plants, the cobbles containing this new fossil are composed of sediments deposited in braided fluvial to costal environments (Cant \& Walker, 1976; Griffing et al., 2000).

The fossils were studied in serial anatomical sections obtained using the cellulose acetate peel technique (Joy, Willis \& Lacey, 1956). Slides for bright-field microscopy were mounted with Eukitt (O. Kindler, Freiburg, Germany) mounting medium. Images were captured using a Nikon Coolpix 8800VR digital camera mounted on a Nikon E400 compound microscope. Material for scanning electron microscopy was obtained from cellulose acetate peels using the method detailed in Matsunaga et al. (2013). SEM images were generated using a FEI Quanta 250 (Hillsboro, Oregon, USA). Images were processed using Adobe Photoshop (San Jose, California, USA). All cobble slabs, acetate peels and slides are stored in the U.S. National Museum of Natural History - Smithsonian Institution (USNM no. 557783-5, 557840, 557790-1, 557790-3).

1
al., 2003; Gerrienne et al., 2006) have discussed the possibility that S-type conducting cells

Several authors (Kenrick \& Crane, 1991; Kenrick, Edwards \& Dales, 1991; Edwards et followed a developmental pathway different from those seen in the tracheids of extant vascular plants. This is contrary to the view of a single origin of tracheids, including S-type conducting cells, in land plants (Cook \& Friedman, 1998). The data we present here do not contribute to this debate in either direction. While acknowledging that it is unclear whether S-type conducting cells are homologous to tracheids, for simplicity we are referring to them as tracheids and to the tissue they form as xylem. For the same reason, we use the term protoxylem to refer to the area comprising the smallest water-conducting cells, and metaxylem for the rest of the waterconducting cells, which are larger, even though developmental evidence for the timing of their maturation with respect to tissue elongation is lacking. 


\section{SYSTEMATICS}

Plesion Rhyniopsida KENRICK \& CRANE

EDDIANNA PFEILER \& TOMESCU GEN. NOV.

Diagnosis: Axes with large amount of xylem and scant extraxylary tissues including phloem and cortex. Cortex sclerenchymatous, irregular, forming anastomosing longitudinal ridges. Central xylem strand terete, with potential centrarch maturation. Tracheids with annular to helical Sennicaulis-type wall thickenings.

Derivation: Eddianna is named in honor of Prof. Dianne Edwards, in recognition of her significant contributions to Silurian and Devonian palaeobotany. Type species: Eddianna gaspiana

\section{EdDianNa GasPiana PFEILER \& TOMESCU SP. NOV.}

Diagnosis: Axes up to $2 \mathrm{~mm}$ or more in diameter, with central xylem strand occupying ca. $80 \%$ of cross-sectional surface area. Cortex sclerenchymatous, at least three cells thick, with cells up to $48 \mu \mathrm{m}$ in diameter. Cortex forms longitudinal ridges up to ca. $190 \mu \mathrm{m}$ tall and $480 \mu \mathrm{m}$ across at the base. Phloem thin, 48-72 $\mu \mathrm{m}$, consisting of 1-3 layers of narrow elongated cells with thin, straight walls. Central xylem strand circular-elliptical in cross section, up to $1.6 \mathrm{~mm}$ or more in diameter. Metaxylem tracheids round to oval in cross section, up to 40-66 $\mu \mathrm{m}$ in diameter. Tracheid wall thickenings with spongy structure and lined with a microporate layer. Wall thickenings ca. $12 \mu \mathrm{m}$ wide, spaced at ca. $24 \mu \mathrm{m}$ apart, and protrude ca. $7 \mu \mathrm{m}$ into the cell lumen. Pore density in microporate layer ca. $16 \mu \mathrm{m}^{-2}$; pore diameter $0.15-0.20 \mu \mathrm{m}$. Larger axes with concentric zonation of the metaxylem: larger tracheids in the outer zone and narrower tracheids in the inner zone; limit between the two zones marked by discontinuous ring of even narrower tracheids.

Derivation of name: gaspiana for the Gaspé Peninsula (Canada) where the specimens were collected.

Holotype: axis in slabs USNM 557840 Gbot, Htop.

Paratypes: axes in slabs USNM 557840 Hbot, 557783-5 Atop, 557790-1 Bbot-Ctop, 557790-3 Atop.

Locality and stratigraphy: Battery Point Formation, in the vicinity of Douglastown; mid- to late Emsian, ca.402-394 Ma. 
153 The axes of E. gaspiana range in diameter from $0.6 \mathrm{~mm}$ to $2.1 \mathrm{~mm}$. The longest observed

154 fragment measures $2.5 \mathrm{~cm}$. Reproductive structures have not yet been found associated with any

155 of the axes. External evidence for axis branching is also missing, although one specimen shows

156 anatomical evidence for branching.

Specimen 557840 Gbot-Htop is an axis cut in cross section (Fig. 1A). The axis is 1.25

$\mathrm{mm}$ in diameter. The cortex consists of highly sclerified cells that form a dark layer in which individual cells are difficult to discern. The thickness of the cortex is variable, including irregular protrusions that range up to $144 \mu \mathrm{m}$ tall and $192 \mu \mathrm{m}$ across the base, as well as regions where the cortex can be very thin $(12 \mu \mathrm{m})$, possibly as a result of incomplete preservation. Beneath the cortex is a thin layer $48 \mu \mathrm{m}$ wide. Cellular preservation in this layer is incomplete, but fragments of cell layers indicate that it consisted of parenchyma cells. Based on its position immediately outside the xylem cylinder, as well as its parenchymatous nature, we interpret this layer as a photosynthate-conducting tissue and refer to it as phloem, while acknowledging that its homology with tracheophyte phloem is equivocal. The central xylem strand is circular in shape, $1.09 \mathrm{~mm}$ in diameter. Although cellular detail is blurred toward the center of the xylem, the centripetal increase in tissue density (Fig. 1A) is consistent with a centrarch pattern of maturation and is, thus, tentatively interpreted as such. Cells walls of the xylem tracheids in this and all other specimens have a conspicuously lighter color compared to the xylem of all other plants in the assemblage. Tracheids have round to oval outlines with diameters up to $30-42 \mu \mathrm{m}$.

173 (Fig. 1B). The cortical cells, easily discernible, are $24-48 \mu \mathrm{m}$ in diameter and have sclerified 174 walls (Fig. 4A). Cortical protrusions are up to $192 \mu \mathrm{m}$ tall and $480 \mu \mathrm{m}$ across at the base. The 175 phloem layer is 50-70 $\mu \mathrm{m}$ wide, and is composed of 1-3 layers of well-preserved thin-walled cells (Fig. 4A). The xylem cylinder is $1.58 \mathrm{~mm}$ diameter and metaxylem tracheids are up to $42-$

$17766 \mu \mathrm{m}$ in diameter. The potential centrarch pattern of xylem maturation is less conspicuous in 178 this specimen, due to the presence of several voids in the central area of the xylem (Fig. 1B); it is 179 unclear if these areas of missing tissue are the result of taphonomy or development. are at least $2.5 \mathrm{~cm}$ in length. In these longitudinal sections, the cortex shows important 
183

184

185

186

187

188

189

190

191

192

193

194

195

196

197

198

199

200

201

202

203

204

205

206

207

208

209

210

211

212

213

cortex is up to $1.2 \mathrm{~mm}$ and individual cells are difficult to discern. The phloem layer is up to 72 $\mu \mathrm{m}$ and 5-6 cells thick, and consists of narrow cells with thin, straight walls (Fig. 3A, B). These cells are elongate, but we did not observe end walls so their length cannot be measured. In a radial longitudinal section the xylem strand is $0.8 \mathrm{~mm}$ in diameter and exhibits more conspicuous centrarch maturation (Fig. 3C). Like in the phloem, the length of the tracheids cannot be measured due to the lack of end walls. Tracheids are up to $48 \mu \mathrm{m}$ in diameter and have annular to helical thickenings. The thickenings are ca. $12 \mu \mathrm{m}$ wide and spaced at ca. $24 \mu \mathrm{m}$ apart. They protrude ca. $7 \mu \mathrm{m}$ into the cell lumen. Scanning electron microscopy revealed the spongy nature of the tracheid wall thickenings (Fig. 3D), which are lined with a microporate inner layer (pore density is ca. $16 \mu \mathrm{m}^{-2}$ and pore diameter ca. 0.15-0.20 $\mu \mathrm{m}$ ) (Fig. 4B). Both these features are characteristic of Sennicaulis-type (S-type) tracheids (Kenrick et al.,1991a).

Specimen 557783-5 Atop is a smaller axis cut in cross section (Fig. 4C). This axis is 1.2 $\mathrm{mm}$ in diameter, with a xylem strand $480 \mu \mathrm{m}$ in diameter. Cellular detail of both the xylem and cortex is not clear as they are both very dense. This specimen is interesting in exhibiting very prominent, irregular cortical protrusions. The protrusions are elongated radially and have blunt or pointed tips; some are branched. Together with the longitudinal sections in 557840 Hbot, this indicates that the sclerenchymatous cortex formed vertical ridges that branched and anastomosed irregularly.

Specimen 557790-3 Atop is a decorticated axis cut in cross section. The xylem has a flattened, oval outline and two areas of protoxylem surrounded by smaller metaxylem tracheids (Fig. 4D). This anatomy reflects branching, which is likely isotomous.

The majority of specimens show subtle yet distinct concentric zonation of the metaxylem (Fig. 1C, D). In the outer zone, tracheids are larger, whereas in the inner zone they are narrower. The limit between the two zones is relatively sharp and marked by a discontinuous ring of even narrower tracheids (Figs. 1B, 3C). Tracheid diameter also decreases slightly toward the periphery of the xylem cylinder (Fig. 1A, B). Tracheids in the outer zone exhibit a subtle radial patterning in shape and arrangement in some areas of the cross sections (Fig. 1A, B).

\section{JUSTIFICATION FOR A NEW GENUS}

According to Kenrick \& Crane (1997), the Rhyniopsida are early tracheophytes with simple organography characterized by adventitious branching of axes and by sporangia that are attached 
214

215

216

217

218

219

220

221

222

223

224

225

226

227

228

229

230

231

232

233

234

235

236

237

238

239

240

241

242

243

244

to a specialized pad of tissue and have an abscission layer at the base. Additionally, all four genera of known rhyniopsids - Rhynia, Sennicaulis, Stockmansella, and Huvenia - have tracheids characterized by S-type wall thickenings (Kenrick \& Crane, 1997; Kenrick et al., 1991a; Kenrick \& Crane, 1991; Kenrick, Remy \& Crane, 1991b). The Eddianna material described here is strictly vegetative and does not provide evidence for adventitious branching. Nevertheless, the presence of S-type tracheid thickenings places this plant among the rhyniopsids, the only group that exhibits this type of tracheids.

Compared to the other rhyniopsid genera (Table 1), Eddianna stands out by its large amount of xylem with respect to the axis diameter and the proportion of extraxylary tissues. Whereas in the other genera the xylem occupies $<10 \%$ of the cross-sectional surface area of axes, in Eddianna the xylem occupies $>80 \%$. On the other hand, while the other rhyniopsids have a thick parenchymatous cortex, Eddianna has very little extraxylary tissues. Additionally, the axes of Eddianna are covered by pronounced longitudinal ridges that branch and anastomose, unlike any of the other rhyniopsids. Finally, it is worth noting that the Eddianna has the largest tracheids of all these plants. Taken together, these differences imply that Eddianna is different form all previously described rhyniopsids, thus warranting erection of a new genus.

All previously known rhyniopsid genera have thick extraxylary tissues. This raises the question of incomplete preservation: could Eddianna represent specimens of a plant with thick parenchymatous extraxylary tissues [such as the compressions referred to as Taeniocrada dubia by Hueber (1982) and "Taeniocrada dubia"/new genus D by Hotton et al. (2001)] that were not preserved? This possibility needs to be considered, since the permineralized plant assemblage that hosts Eddianna is allochthonous, therefore the plant material underwent transport which may have affected its integrity. Additionally, an epidermal layer cannot be distinguished on the Eddianna axes. This could be explained either by sclerification of the epidermis along with the underlying cortical layers or by loss, which would indicate incompleteness of preservation of extraxylary tissues.

Of the relatively numerous (18) specimens studied, none shows evidence of tissues, even incomplete, outside the sclerenchymatous cortex. Instead, fragments of other plants are found alongside and in contact with the sclerenchymatous cortex of Eddianna axes. On one hand, these are consistent with an interpretation of the Eddianna specimens as being anatomically complete as described here. On the other hand, there observations do not unequivocally reject 
the hypothesis of taphonomic loss of a putative parenchymatous outer cortex. However, it is important to note that the multiple Eddianna specimens are found in four separate rock samples that exhibit differences in grain size (from silt-size to microconglomerate). This observation has two implications: (i) the specimens come from different populations, thus they have undergone transport over different distances; and (ii) they underwent transport under different flow regimes. Consequently, our sample of Eddianna specimens covers a whole range of intensities of exposure to taphonomic factors. This makes it likely that at least fragments of an outer parenchymatous cortex, if such a layer was present, would have been preserved in at least some of the specimens. Because we observed no such structures, the interpretation that Eddianna had an outer parenchymatous cortex that was not preserved, is not supported by any physical evidence. Instead, the weight of all evidence associated with the Eddianna specimens supports the hypothesis that an outer parenchymatous cortex was not present and the specimens preserve relatively complete anatomy of the axes, which we adopt as our interpretation of these fossils.

\section{FUNCTIONAL ANATOMY AND THE EDDIANNA PLANT}

The thick sclerified cortex of Eddianna could have had a role in providing both mechanical support for the axes and protection from desiccation and herbivory (i.e. piercing-and-sucking; Labandeira \& Currano, 2013). The primarily sclerenchymatous nature of the cortex also indicates that this layer had little to no photosynthetic capabilities. Additionally, the only other extraxylary tissue of the Eddianna axes is a thin phloem layer. Together, these suggest that Eddianna axes were not photosynthetic. Concurrently, the axes have a high proportion of xylem which is consistent with high water transport capacity. Together, the lack of photosynthetic tissues and the high water transfer capacity of the axes suggest that they represent the lower portions of larger plants that conducted photosynthesis in more distal parts of hypothetical branching systems. Therefore, the lower portions of these plants consisted of stiff, nonphotosynthetic axes built for maximizing support and water transport.

Basal axes that have almost exclusively a water conduction role, such as those of Eddianna, are justified only if (1) water is readily available in the substrate; (2) the plants have an extensive absorptive rooting system or (3) they have extensively developed distal photosynthetic parts; or a combination of these conditions. Therefore, it is likely that the Eddianna plant grew in a water-rich environment, e.g. in the immediate vicinity of water bodies, 
on floodplains, or on substrates with a high water table. Alternatively, the distal photosynthetic parts of Eddianna could have been extensively developed (highly branched), or had rapid growth, or maintained high turgidity, all of which require high water intake. It is also worth considering that rhyniopsids have adventitious branching (Kidston \& Lang, 1917; Kenrick \& Crane, 1997; Kearney, Kerp \& Hass, 2016) wherein lateral axes, attached to the plant by constricted bases marked by a discontinuous vascular strand, could be abscised and act as propagules (Kearney et al., 2016). This rhyniopsid feature suggests yet another possible explanation for the high xylem volume of Eddianna axes: high turnover of distal photosynthetic parts by abscission of such adventitious deciduous branches, which would have also required high water use.

The concentric zonation observed in the xylem of Eddianna axes is puzzling. Although weak/faint radial patterning is present in some xylem sectors of these axes, this does not provide evidence for secondary growth. Therefore, the concentric zonation cannot be attributed to variations in growth rhythm of a lateral meristem (cambium). However, this concentric pattern is consistently present in many Eddianna specimens, which indicates that it reflects a constitutive feature of development in this plant.

\section{RHYNIOPSIDS IN THE BATTERY POINT FORMATION FLORA}

Because Eddianna is a rhyniopsid, a logical question is: are these fossils part of another, previously described, rhyniopsid from the Battery Point Formation? Rhyniopsids reported previously from the Battery Point Formation include only compression fossils: Huvenia sp. nov. (Hotton et al., 2001), a type referred to as 'new genus D' or “Taeniocrada dubia" (Hotton et al., 2001 and Hueber 1982), and fossils referred to as Stockmansella (Hotton et al., 2001) or cf. Stockmansella (Gensel, 2005). Huvenia sp. nov. axes are about $5 \mathrm{~mm}$ in diameter and the axes of new genus D (“Taeniocrada dubia") are 9-20 mm in diameter (Hotton et al., 2001). The sizes of cf. Stockmansella axes in the Battery Point Formation are not reported, but the axes of the two Stockmansella species described to date are 2-15 mm in diameter (Fairon-Demaret, 1985; Schultka \& Hass, 1997). With the exception of the smallest Stockmansella specimens, all of these plants have axes that are much wider than those of Eddianna. Structurally speaking, in most plants, growth and branching patterns lead to progressively thinner axes distally. 
are predicted to consist of axes of smaller diameter than the lower portions. Consequently, the distal parts of the Eddianna plant would be much thinner than the axes of the rhyniopsids previously described from the Battery Point Fomation. This excludes these other rhyniopsids as potential candidates for the distal parts of Eddianna, the search for which is ongoing.

\section{CONCLUSIONS}

We are describing a new anatomically preserved plant from Emsian deposits of the Battery Point Formation (Gaspé, Canada). The plant, Eddianna gaspiana gen. et sp. nov., has distinctive anatomy characterized by a thick xylem strand with S-type tracheids and a ridged sclerenchymatous cortex, which set it apart from previously described rhyniopsids. The anatomy of Eddianna fossils indicates that they represent the lower portions of a plant whose distal regions have yet to be discovered. Eddianna is the first anatomically preserved rhyniopsid reported from the Battery Point Formation. This unit has already yielded compression fossils potentially representing three types of rhyniopsids, but the size of these rhyniopsid axes is inconsistent with predicted sizes of the distal parts of Eddianna.

Eddianna adds a fourth type to the diversity of plants known from anatomically preserved specimens in the Battery Point Formation. Previously described permineralized fossils represent trimerophytes - Psilophyton (Banks et al., 1975), Franhueberia (Hoffman \& Tomescu, 2013) and a third unnamed type (Gensel, 1984) - and a zosterophyll (Crenaticaulis; Banks \& Davis, 1969). In contrast, the compressions in the Battery Point Formation represent a higher diversity of plants (Gensel \& Andrews, 1984; Hotton et al., 2001; Gensel, 2005). This higher diversity should be mirrored in the permineralized component of the flora. Together, these suggest that the Battery Point Formation hosts additional diversity of permineralized species that await in-depth investigation. This study is part of renewed efforts to characterize this diversity.

\section{ACKNOWLEDGEMENTS}

We thank Francis M. Hueber, who collected the specimens containing Eddianna axes. We are indebted to William DiMichele, Carol Hotton and Jonathan Wingerath (National Museum of Natural History - Smithsonian Institution) for facilitating specimen loans; Kelly K.S. Matsunaga (University of Michigan) for help during work in the NMNH collections; and Alejandro C. 
microscopy. The research has been supported by a grant (to AMFT) from the American Philosophical Society, which is gratefully acknowledged.

\section{REFERENCES}

Banks HP. 1970. Major evolutionary events and the geological record of plants. Biological Reviews 45: 451-454.

Banks HP. 1981. Peridermal activity (wound repair) in an early Devonian (Emsian) trimerophyte from the Gaspé Peninsula, Canada. Palaeobotanist 28-29: 20-25.

Banks HP, Colthart BJ. 1993. Plant-animal-fungal interactions in the Early Devonian Trimerophytes from Gaspé, Canada. American Journal of Botany 80: 992-1001.

Banks HP, Davis MR. 1969. Crenaticaulis, a new genus of Devonian plants allied to Zosterophyllum, and its bearing on the classification of early land plants. American Journal of Botany 56: 436-449.

Banks HP, Leclercq, Hueber FM. 1975. Anatomy and morphology of Psilophyton dawsonii, sp. n. from the late Lower Devonian of Québec (Gaspé) and Ontario, Canada. Palaeontographica Americana 8: 73-127.

Cant DJ, Walker G. 1976. Development of a braided-fluvial facies model for the Devonian Battery Point Sandstone, Québec. Canadian Journal of Earth Sciences 13: 102-119.

Cascales-Miñana B, Munoz-Bertomeu J, Ros R, Segura J. 2010. Trends and patterns in the evolution of vascular plants: macroevolutionary implications of a multilevel taxonomic analysis. Lethaia 43: 545-557.

Cohen KM, Finney S, Gibbard PL, Fan J-X. 2016. International chronostratigraphic chart. International Commission on Stratigraphy. Available at http://www.stratigraphy.org/ICSchart/ChronostratChart2016-12.pdf.

Cook ME, Friedman WE. 1998. Tracheid structure in a primitive extant plant provides an evolutionary link to earliest fossil tracheids. International Journal of Plant Sciences 159: 881-890.

Dawson JW. 1859. On fossil plants from the Devonian rocks of Canada. Quarterly Journal of the Geological Society of London 15: 477-488. 
Edwards D. 1980. Evidence for the sporophytic status of the lower Devonian plant Rhynia gwynne-vaughanii Kidston and Lang. Review of Palaeobotany and Palynology 29: 177185.

Edwards D. 1981. Studies on Lower Devonian petrifactions from Britain. 2. Sennicaulis, a new form genus for sterile axes based on pyrite and limonite petrifactions from the Senni Beds. Review of Palaeobotany and Palynology 32: 207-226.

Edwards D, Axe L, Duckett JG. 2003. Diversity in conducting cells in early land plants and comparisons with extant bryophytes. Botanical Journal of the Linnean Society 141: 297347.

Fairon-Demaret M. 1985. Fossil plants from the Emsian of Sart Tilman, Belgium. I. Stockmansia langii (Stockmans) comb. nov. (in French). Review of Palaeobotany and Palynology 44: 243-260.

Fairon-Demaret M. 1986. Stockmansella, a new name for Stockmansia Fairon-Demaret (fossil). Taxon 35: 334.

Gensel PG. 2005. Gaspé Sandstone Group - Lower to Middle Devonian. In: Bourque P-A, Desbiens S, Gensel PG, eds. Silurian-Devonian Biota and paleoenvironments of Gaspé Peninsula and northern New Brunswick. North America Paleontological Convention 2005, Halifax, Nova Scotia, field trip guide. 100-116.

Gensel PG. 2008. The earliest land plants. Annual Review of Ecology Evolution and Systematics 39: $459-477$.

Gensel PG, Andrews HN. 1984. Plant life in the Early Devonian. New York: Praeger Publishers.

Gensel PG, Berry CM. 2016. Sporangial morphology of the Early Devonian zosterophyll Sawdonia ornata from the type locality (Gaspe). International Journal of Plant Sciences 177: 618-632.

Gensel PG, Edwards D. 2001. Plants invade the land. New York: Columbia University Press. Gerrienne P, Dilcher DL, Bergamaschi D, Milagres I, Pereira E, Antonieta RC. 2006. An exceptional specimen of the early land plant Cooksonia paranensis, and a hypothesis on the life cycle of the earliest eutracheophytes. Review of Palaeobotany and Palynology 142: 123-130. 
402

403

404

405

406

407

408

409

410

411

412

413

414

415

416

417

418

419

420

421

422

423

424

425

426

427

Griffing DH, Bridge JS, Hotton CL. 2000. Coastal-fluvial palaeoenvironments and plant palaeoecology of the Lower Devonian (Emsian), Gaspé Bay, Québec, Canada. In P. F. Friend and B. P. J. Williams eds. New perspectives on the Old Red Sandstone. London, UK: Geological Society, 61-84.

Hao SG, Xue JZ. 2013. The Early Devonian Posongchong Flora of Yunnan. Beijing: Science Press.

Hartman CM. 1981. The effect of pyrite on the tracheid structure of Drepanophycus spinaeformis, a long-range Devonian lycopod. Review of Palaeobotany and Palynology 32: 239-255.

Hartman CM, Banks HP. 1980. Pitting in Psilophyton dawsonii, an Early Devonian trimerophyte. American Journal of Botany 67: 400-412.

Hass H, Remy W. 1991. Huvenia kleui nov. gen., nov. spec. - a rhyniophyte from the upper Siegenian of the Rheinischen Schiefergebirges (in German). Argumenta Paleobotanica 8: 141-168.

Hoffman LA, Tomescu AMF. 2013. An early orgin of secondary growth: Franhueberia gerriennei gen. et sp. nov. from the Lower Devonian of Gaspé Bay (Québec, Canada). American Journal of Botany 100: 754-763.

Hotton CL, Hueber FM, Griffing DH, Bridge JS. 2001. Early terrestrial plant environments: an example from the Emsian of Gaspé, Canada. In: Gensel PG, Edwards D, eds. Plants invade the land. New York: Columbia University Press, 179-212.

Hueber FM. 1982. Taeniocrada dubia Kr. and W.: its conducting strand of helically strengthened tubes. Botanical Society of America Miscellaneous Series 162: 58-59.

Joy KW, Willis AJ, Lacey S. 1956. A rapid cellulose peel technique in paleobotany. Annals of Botany 20: 635-637.

Kearney P, Kerp H, Hass H. 2016. Whole-plant regeneration via epidermal cells in the axis of the Early Devonian Rhynie Chert plant Rhynia Gwynne-vaughanii Kidston et Lang. International Journal of Plant Sciences 177: 539-550.

Kenrick P, Crane PR. 1991. Water-conducting cells in early fossil land plants: implications for the early evolution of Tracheophytes. Botanical Gazette 152: 335-356.

Kenrick P, Crane PR. 1997. The origin and early diversification of land plants. Washington and London: Smithsonian Institution Press. 
428

429

Kenrick P, Edwards D, Dales RC. 1991. Novel ultrastructure in water conducting cells of the Lower Devonian plant Sennicaulis hippocrepiformis. Palaeontology 34: 751-766.

Kenrick P, Remy W, Crane PR. 1991. The structure of water-conducting cells in the enigmatic early land plants Stockmansella langii Fairon-Demaret, Huvenia kleui Hass et Remy and Sciadophyton sp. Remy et al. 1980. Argumenta Palaeobotanica 8: 179-191.

Kidston R, Lang WH. 1917. On Old Red Sandstone plants showing structure from the Rhynie Chert Bed, Aberdeenshire. Part I. Rhynia gwyne-vaughani. Transactions of the Royal Society of Edinburgh 51: 761-784.

Labandeira CC, Currano ED. 2013. The fossil record of plant-insect dynamics. Annual Review of Earth and Planetary Sciences 41: 287-311.

Matsunaga KKS, Stockey RA, Tomescu AMF. 2013. Honeggeriella complexa gen. et. sp. nov., a heteromerous lichen from the Lowe Cretaceous of Vancouver Island (British Columbia, Canada). American Journal of Botany 100: 450-459.

McGregor DC. 1977. Lower and Middle Devonian spores of Eastern Gaspé, Canada. II. Biostratigraphy. Palaeontographica Abt. B 163: 111-142.

Schultka S. 1991. Huvenia elongata nov. spec. (ex. form genus Taeniocrada White 1913) in the upper Emsian of the Rheinischen Schiefergebirges (in German). Argumenta Palaeobotanica 8: 169-178.

Schultka S, Hass H. 1997. Stockmansella remyi sp. nov. from the Eifelian: new aspects in the Rhyniaceae (sensu Hass et Remy, 1991). Review of Palaeobotany and Palynology 97: 381-393. 
Figure 1. Eddianna gaspiana gen. \& sp. nov. A, B, Axis cross sections exhibiting large primary xylem with potential centrarch maturation cylinders separated from thin, irregular sclerenchymatous cortex by a thin layer of phloem; note incomplete preservation of xylem at center in B. C, D, same images as in A and B, respectively, colorized to emphasize concentric zonation of the metaxylem, with larger tracheids in the outer zone (yellow) and narrower tracheids in the inner zone (brown); a thin discontinuous layer of very fine tracheids (more conspicuous in B, D) marks the border between the two zones; note subtle radial patterning of tracheids, locally, in the outer zone, and pattern of decreasing tracheid diameter toward xylem periphery. A, C, USNM-557840 Htop \#20a; B, D, USNM-557790-1 Bbot \#88a. Scale bars = $300 \mu \mathrm{m}$.

Figure 2. Eddianna gaspiana gen. \& sp. nov. A, Three Eddianna axes (asterisks); one is sectioned transversally and the other two longitudinally; the other plant material is Psilophyton. USNM-557840 Hbot \#117f. Scale bar $=2 \mathrm{~mm}$. B, Oblique longitudinal section of axis with prominent xylem strand (light brown) and dark, sclerenchymatous cortex forming anastomosing longitudinal ridges (very pronounced on the right). USNM-557840 \#1f. Scale bar $=600 \mu \mathrm{m}$.

Figure 3. Eddianna gaspiana gen. \& sp. nov. A, B, Longitudinal sections of axis showing

468 (right to left in A and left to right in B) metaxylem tracheids (light brown) with conspicuous 469 helical wall thickenings; phloem layer (light brown) with narrow cells and fine, straight vertical cell walls; and incompletely preserved sclerenchymatous cortex (dark brown). Scale bars $=50$

$471 \mu \mathrm{m}$. C, Longitudinal radial section of axis with large xylem strand (protoxylem compressed, 472 distorted at center); sclerenchymatous cortex (dark brown, at left and right); and thin phloem 473 sandwiched between xylem and cortex; note conspicuous helical thickenings of metaxylem 474 tracheids and fine band of much narrower tracheids (between arrowheads) between the two 475 concentric zones of the metaxylem (e.g. Fig. 1B, 1D). Scale bar $=150 \mu \mathrm{m}$. USNM-557840

476 Hbot \#1f. D, Scanning electron micrograph of tracheids with helical wall thickenings, note 477 spongy structure of the thickenings, characteristic of Sennicaulis-type tracheids. USNM-557840 Hbot \#44. Scale bar $=10 \mu \mathrm{m}$. 
479 Figure 4. Eddianna gaspiana gen. \& sp. nov. A, Cross section of axis; here the cortex (left)

480 has larger cells with thinner walls, some filled with dark content; the 2-3 cells-thick phloem is

481 somewhat compressed between the cortex and metaxylem; the metaxylem (right) shows robust

482 helical wall thickenings. USNM-557790-1 Bbot \#88a. Scale bar $=100 \mu \mathrm{m}$. B, Scanning

483 electron micrograph of the microporate inner lining of the Sennicaulis-type tracheid wall.

484 USNM-557840 Hbot \#44. Scale bar $=2 \mu \mathrm{m}$. C, Cross section of smaller axis with well-

485 developed sclerenchymatous cortex; note numerous robust irregular protrusions of the cortex,

486 which form anastomosing longitudinal ridges along axes. USNM-557783-5 Atop \#8a. Scale bar

$487=200 \mu \mathrm{m}$. D, Cross section of decorticated axis at branching point, exhibiting elliptical xylem

488 with two protoxylem strands. USNM-557790-3 Atop \#30a. Scale bar $=200 \mu \mathrm{m}$. 
Table 1. Rhyniopsid genera compared.

\begin{tabular}{|c|c|c|c|c|c|}
\hline & Eddianna & Stockmansella & Huvenia & Sennicaulis & Rhynia \\
\hline Max. axis diameter & $2.1 \mathrm{~mm}$ & $15.0 \mathrm{~mm}$ & $15.0 \mathrm{~mm}$ & $6.0 \mathrm{~mm}$ & $2.0 \mathrm{~mm}$ \\
\hline$\%$ Xylem surface & 82.0 & $0.7-2.6$ & $1.6-6.3$ & 2.3 & 0.5 \\
\hline $\begin{array}{l}\text { Max. tracheid } \\
\text { lumen diameter }\end{array}$ & $67 \mu \mathrm{m}$ & $50 \mu \mathrm{m}$ & $27 \mu \mathrm{m}$ & $45 \mu \mathrm{m}$ & $21 \mu \mathrm{m}$ \\
\hline $\begin{array}{l}\text { Tracheid wall } \\
\text { thickening width }\end{array}$ & $6.0-21.6 \mu \mathrm{m}$ & $4.7-9.5 \mu \mathrm{m}$ & $3.5-6.3 \mu \mathrm{m}$ & $6.3-27.5 \mu \mathrm{m}$ & $10.7 \mu \mathrm{m}$ \\
\hline Extraxylary tissues & $\begin{array}{l}\text { overall thin; thin-walled } \\
\text { phloem cells, } \\
\text { sclerenchymatous cortex }\end{array}$ & $\begin{array}{l}\text { thick cortex } \\
\text { ?parenchymatous }\end{array}$ & $\begin{array}{l}\text { thick cortex } \\
\text { ?parenchymatous }\end{array}$ & $\begin{array}{c}\text { thick cortex ?parenchymatous } \\
\text { thick-walled cells in outermost } \\
\text { layers }\end{array}$ & $\begin{array}{l}\text { thick cortex } \\
\text { parenchymatous }\end{array}$ \\
\hline $\begin{array}{l}\text { Projections on } \\
\text { axis surface }\end{array}$ & $\begin{array}{l}\text { low cones; irregular } \\
\text { anastomosing ridges }\end{array}$ & $\begin{array}{l}\text { hemispherical rhizoid- } \\
\text { bearing bulges }\end{array}$ & $\begin{array}{l}\text { longitudinally ovoid low } \\
\text { relief }\end{array}$ & ?smooth & $\begin{array}{c}\text { hemispherical rhizoid- } \\
\text { bearing bulges }\end{array}$ \\
\hline Age & Emsian & Pragian - Eifelian & Pragian - Emsian & Pragian & Pragian \\
\hline Location & Québec, Canada & Belgium, Germany & Germany & Wales & Scotland \\
\hline Preservation & $\begin{array}{c}\text { carbonate } \\
\text { permineralization }\end{array}$ & $\begin{array}{l}\text { compression, tracheid } \\
\text { casts }\end{array}$ & $\begin{array}{l}\text { compression, tracheid } \\
\text { casts }\end{array}$ & $\begin{array}{l}\text { pyrite-limonite } \\
\text { permineralization }\end{array}$ & $\begin{array}{c}\text { silica } \\
\text { permineralization }\end{array}$ \\
\hline References & this study & $\begin{array}{l}\text { Fairon-Demaret 1985; } \\
\text { Schultka \& Hass } 1997\end{array}$ & $\begin{array}{c}\text { Hass \& Remy 1991; } \\
\text { Shultka 1991; Kenrick \& } \\
\text { Crane 1991; Schultka \& } \\
\text { Hass } 1997\end{array}$ & $\begin{array}{c}\text { Edwards 1981; Kenrick et al. } \\
1991\end{array}$ & $\begin{array}{c}\text { Kidston \& Lang 1917; } \\
\text { Edwards } 1980\end{array}$ \\
\hline
\end{tabular}




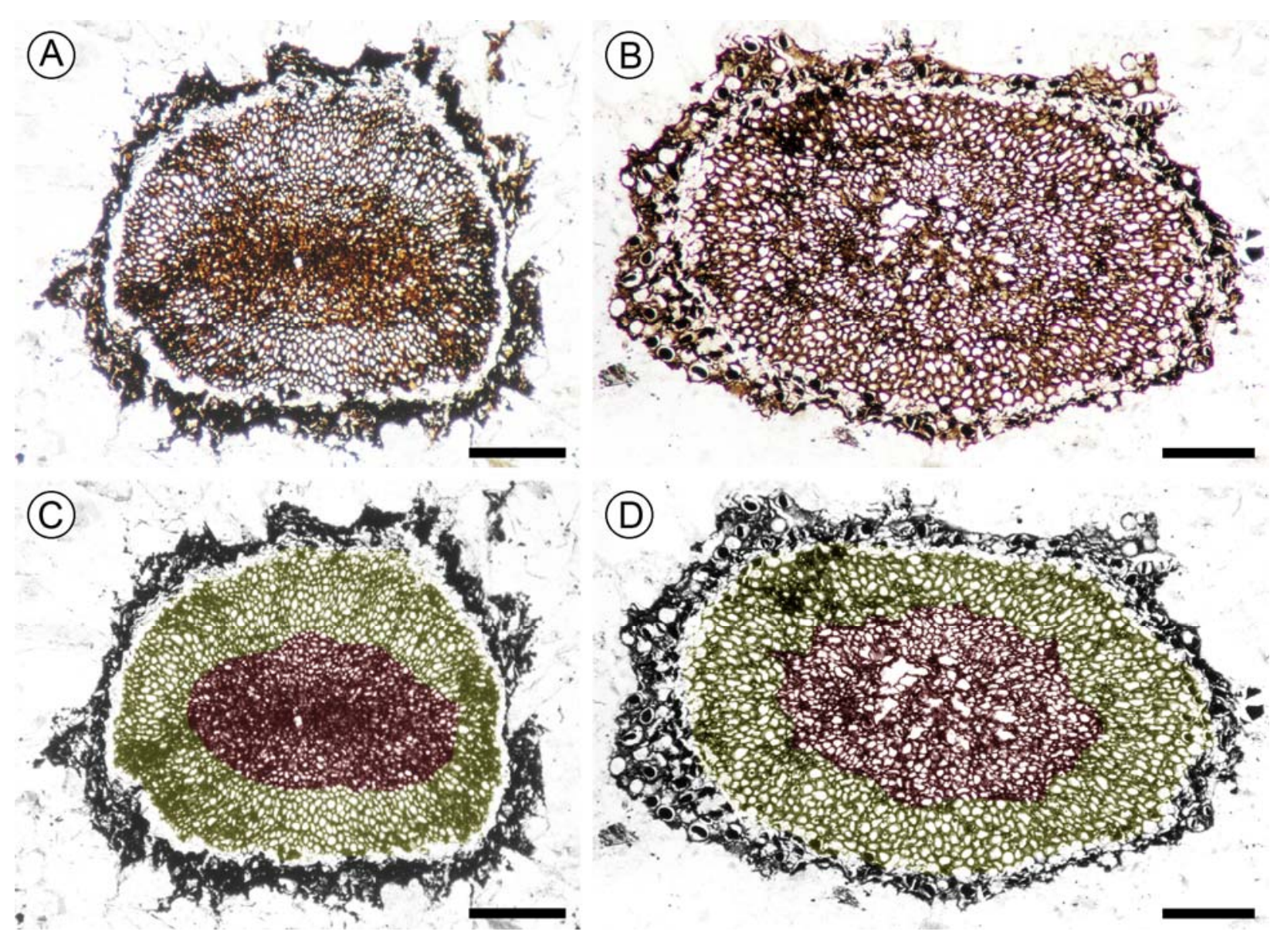

Figure 1. Eddianna gaspiana gen. \& sp. nov. A, B, Axis cross sections exhibiting large primary xylem with potential centrarch maturation cylinders separated from thin, irregular sclerenchymatous cortex by a thin layer of phloem; note incomplete preservation of xylem at center in B. C, D, same images as in A and B, respectively, colorized to emphasize concentric zonation of the metaxylem, with larger tracheids in the outer zone (yellow) and narrower tracheids in the inner zone (brown); a thin discontinuous layer of very fine tracheids (more conspicuous in B, D) marks the border between the two zones; note subtle radial patterning of tracheids, locally, in the outer zone, and pattern of decreasing tracheid diameter toward xylem periphery. A, C, USNM-557840 Htop \#20a; B, D, USNM-557790-1 Bbot \#88a. Scale bars = $300 \mu \mathrm{m}$. 


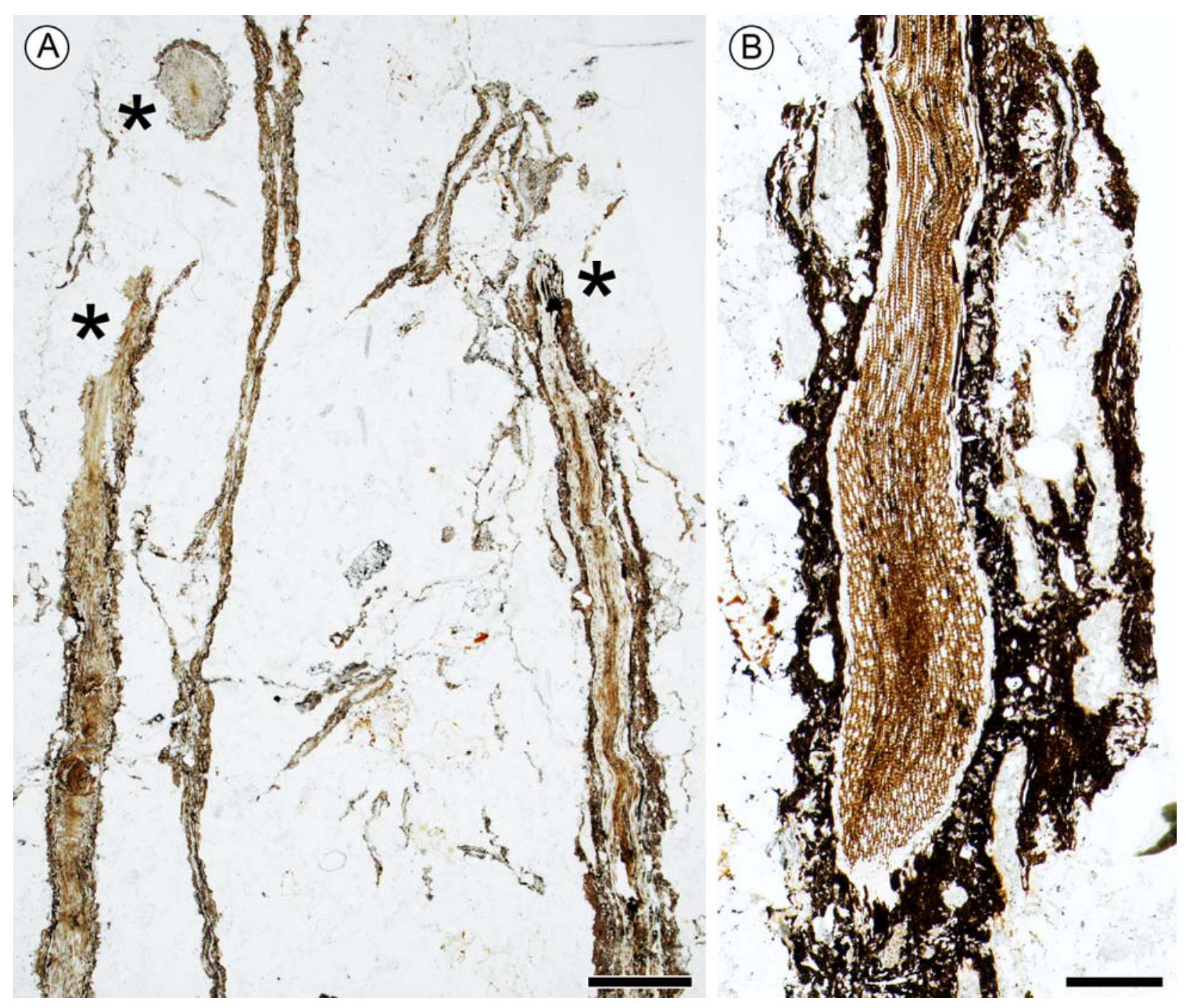

Figure 2. Eddianna gaspiana gen. \& sp. nov. A, Three Eddianna axes (asterisks); one is sectioned transversally and the other two longitudinally; the other plant material is Psilophyton. USNM-557840 Hbot \#117f. Scale bar $=2 \mathrm{~mm}$. B, Oblique longitudinal section of axis with prominent xylem strand (light brown) and dark, sclerenchymatous cortex forming anastomosing longitudinal ridges (very pronounced on the right). USNM-557840 \#1f. Scale bar $=600 \mu \mathrm{m}$. 


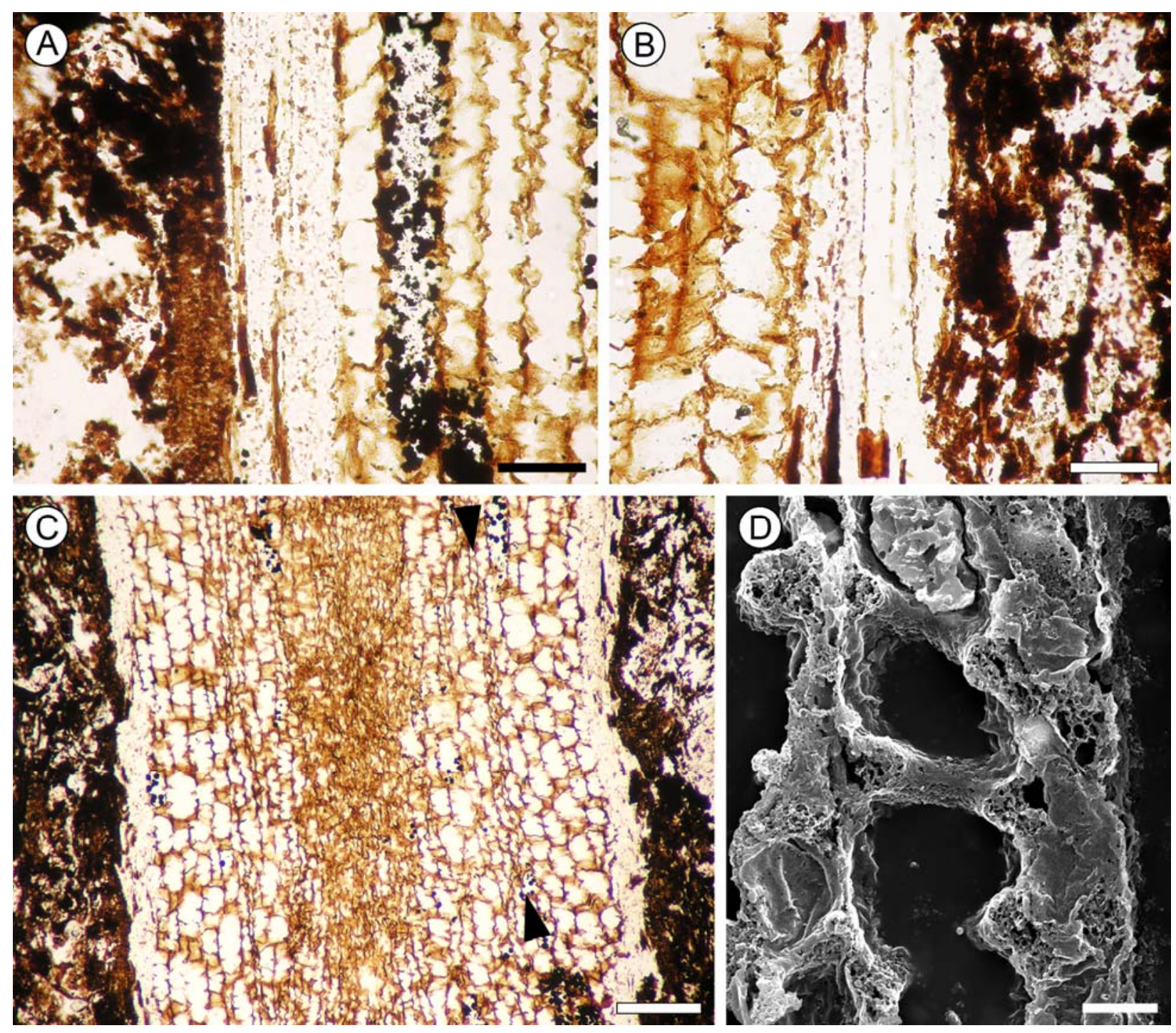

Figure 3. Eddianna gaspiana gen. \& sp. nov. A, B, Longitudinal sections of axis showing

(right to left in A and left to right in B) metaxylem tracheids (light brown) with conspicuous helical wall thickenings; phloem layer (light brown) with narrow cells and fine, straight vertical cell walls; and incompletely preserved sclerenchymatous cortex (dark brown). Scale bars $=50$ $\mu \mathrm{m}$. C, Longitudinal radial section of axis with large xylem strand (protoxylem compressed, distorted at center); sclerenchymatous cortex (dark brown, at left and right); and thin phloem sandwiched between xylem and cortex; note conspicuous helical thickenings of metaxylem tracheids and fine band of much narrower tracheids (between arrowheads) between the two concentric zones of the metaxylem (e.g. Fig. 1B, 1D). Scale bar $=150 \mu \mathrm{m}$. USNM-557840 Hbot \#1f. D, Scanning electron micrograph of tracheids with helical wall thickenings, note spongy structure of the thickenings, characteristic of Sennicaulis-type tracheids. USNM-557840 Hbot \#44. Scale bar $=10 \mu \mathrm{m}$. 

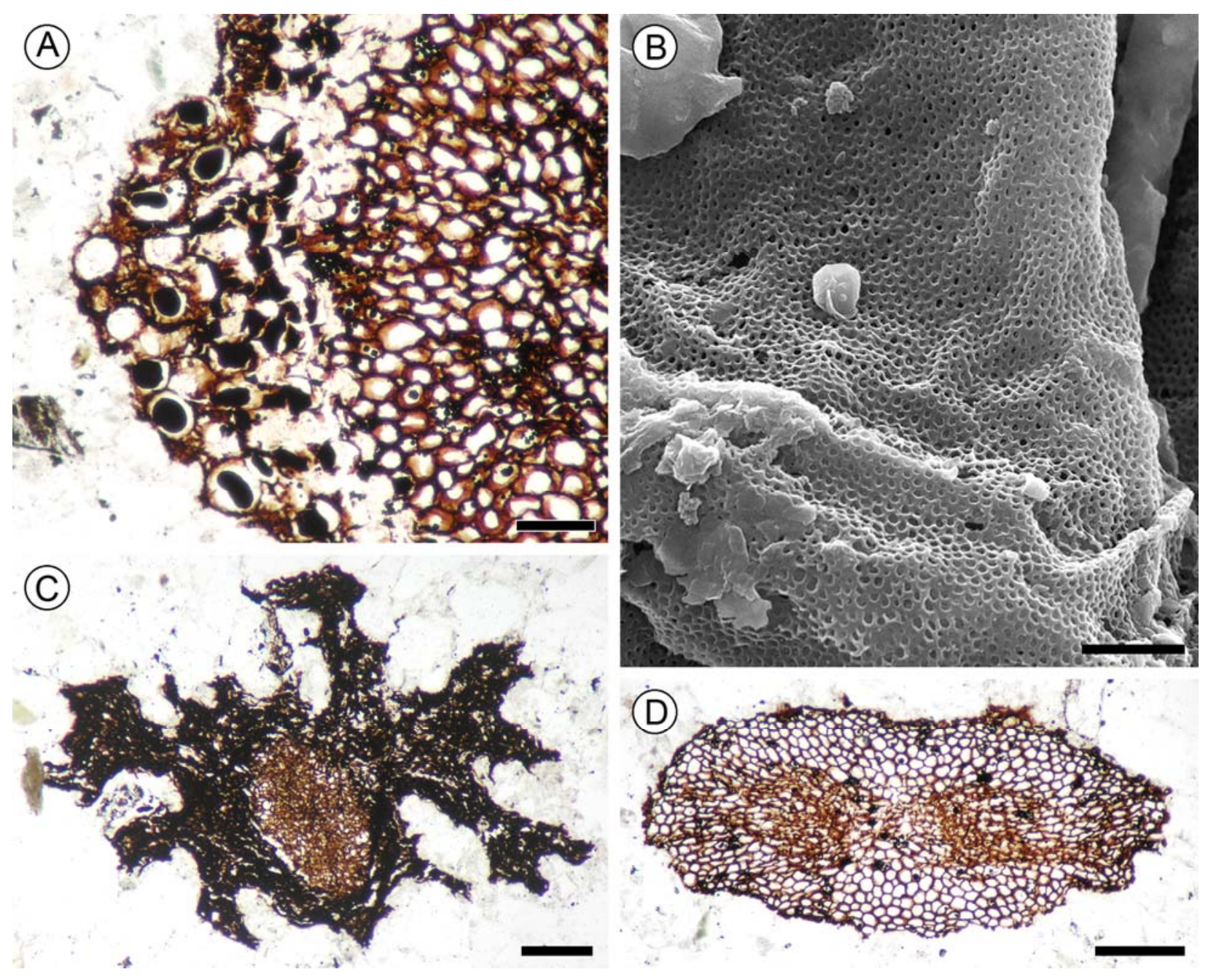

Figure 4. Eddianna gaspiana gen. \& sp. nov. A, Cross section of axis; here the cortex (left)

has larger cells with thinner walls, some filled with dark content; the 2-3 cells-thick phloem is somewhat compressed between the cortex and metaxylem; the metaxylem (right) shows robust helical wall thickenings. USNM-557790-1 Bbot \#88a. Scale bar $=100 \mu \mathrm{m}$. B, Scanning electron micrograph of the microporate inner lining of the Sennicaulis-type tracheid wall. USNM-557840 Hbot \#44. Scale bar $=2 \mu \mathrm{m}$. C, Cross section of smaller axis with welldeveloped sclerenchymatous cortex; note numerous robust irregular protrusions of the cortex, which form anastomosing longitudinal ridges along axes. USNM-557783-5 Atop \#8a. Scale bar $=200 \mu \mathrm{m}$. D, Cross section of decorticated axis at branching point, exhibiting elliptical xylem with two protoxylem strands. USNM-557790-3 Atop \#30a. Scale bar $=200 \mu \mathrm{m}$. 